\title{
Silage of rehydrated corn grain
}

[Silagem de grão de milho reidratado]

\author{
M.A. Mombach ${ }^{1}$, D.H. Pereira ${ }^{2 *}$, D.S. Pina ${ }^{3}$, D.C Bolson ${ }^{4}$, B.C. Pedreira ${ }^{5}$
}

\author{
${ }^{1}$ Universidade Federal do Mato Grosso - Cuiabá, MT \\ ${ }^{2}$ Universidade Federal do Mato Grosso - Sinop, MT \\ ${ }^{3}$ Universidade Federal da Bahia - Salvador, BA \\ ${ }^{4}$ Fortuna Nutrição Animal - Nova Canaã - MT \\ ${ }^{5}$ Embrapa Agrossilvipastoril - Sinop, MT
}

\begin{abstract}
The objective with this study was to evaluate the effect of different levels of water inclusion on the chemical composition and fermentation profiles of reconstituted corn grain silage. The experiment was carried out in a factorial arrangement in a completely randomized design, with three replicates per treatment. Five treatments were evaluated with different levels of water inclusion (\% of the natural matter): dry corn grain (control); $90 \%$ dry corn grain (DCG) and 10\% water; $80 \%$ DCG and $20 \%$ water; $70 \%$ DGC and $30 \%$ water; and 60\% DCG and 40\% water, totaling 45 experimental silos. Inclusion of water in the silage of reconstituted corn grain promoted a reduction in the CP (\%) and NDF (\%) contents. However, the water increase elevated the NPN/TN contents and the amount of effluent, gas and dry matter (\%) losses. The treatment with inclusion of $30 \%$ water in the natural matter leads to a better fermentation profile and fewer losses of effluent and dry matter, so it is recommended for ensiling dry ground corn grain.
\end{abstract}

Keywords: water, concentrate, ensiling, fermentation, moisture

\section{RESUMO}

Objetivou-se avaliar o efeito de diferentes níveis de inclusão de água na composição química e no perfil fermentativo de silagem de grão de milho reidratado. O experimento foi conduzido em esquema fatorial, em um delineamento inteiramente ao acaso. Cinco tratamentos com diferentes níveis de inclusão de água (\% da matéria natural) foram avaliados: milho grão seco (controle); $90 \%$ de milho grão seco (MGS) e $10 \%$ de água; $80 \%$ de MGS e $20 \%$ de água; $70 \%$ de MGS e $30 \%$ de água e $60 \%$ de MGS e $40 \%$ de água, totalizando 45 silos experimentais. A inclusão de água na silagem do grão de milho reconstituído promoveu redução nos conteúdos de PB (\% MS) e FDN (\% MS). Contudo, o incremento de água aumentou os teores de NNP/NT e as perdas por efluente, gás e matéria seca. $O$ tratamento com a inclusão de $30 \%$ de água na matéria natural propicia um melhor perfil fermentativo e menores perdas por efluente e matéria seca, sendo recomendado para a ensilagem de grão de milho seco moído.

Palavras-chave: água, concentrado, ensilagem, fermentação, umidade

\section{INTRODUCTION}

Corn (Zea mays) is one of the main ingredients used in animal feeding in Brazil and worldwide, mostly because of its availability and nutritive quality. However, depending on the annual production and distance from the production

Recebido em 12 de dezembro de 2016

Aceito em 18 de outubro de 2018

*Autor para correspondência (corresponding author)

E-mail: daltonhenri@ufmt.br centers, this ingredient might raise the cost of animal production.

Nevertheless, in some states of Brazil, such as Mato Grosso, these problems are not the main obstacles to the use of corn in animal feeding. The production of second crop corn in this state is high, accounting for $45.8 \%$ of the national 
production of this culture, with an estimated yield of 25.25 million tons to 2018 (Levantamento..., 2018).

Because of favorable planting conditions, the crops from recent years have been breaking records, leading to a surplus of this product in the market. Still, an increase in production is not followed by improvement in transportation logistics, and especially storage. Problems concerning the difficulties of distribution of this production and lack of warehouses are often seen in the media in this state, which sometimes precludes the productive system. Because of this situation, it is often observed that thousands of tons of grains are wasted annually both on highways and overflowing-warehouse yards.

An alternative for this corn-storage deficiency in producing regions could be the ensiling process of corn grains reconstituted at the very property, which consists of adding water to the dry ground corn grains until they reach the right moisture content to be ensiled (Mombach et al., 2018).

The adoption of this technique allows for elimination or considerably reduced development of fungi, (Reis et al., 2001), to improve the starch digestibility of corn (Ferraretto et al., 2018) and nutrients utilization by ruminants (McAllister et al., 1993). Moreover, to the small and medium and farmer, this technique allows to reduce production costs and losses caused by the attack of bugs and rodents, which is very common in grains deposited in warehouses.

However, the success in the use of silage of reconstituted corn grain is highly affected by the rehydration process and by the proper employment of different ensiling techniques. Therefore, the objective of this study was to evaluate the effect of different levels of water inclusion on the chemical composition and fermentation profile of silages of reconstituted coarsely-ground corn grain silages, and thus know its silage potential.

\section{MATERIALS AND METHODS}

The experiment was conducted at the Animal Nutrition and Forage Laboratory at Federal University of Mato Grosso (UFMT), Campus Sinop. The dry corn grain acquired in the region, was disintegrated in a mill with 5-mm mesh sieve as usually done in the field, and then it was reconstituted with water. Five levels of water inclusion ( $\%$ of the natural matter) in the silage of corn were evaluated, making up the following treatments: T1 - dry corn grain (control); T2 $90 \%$ dry corn grain (DCG) and $10 \%$ water; T3 $80 \%$ DCG and $20 \%$ water; T4 - 70\% DGC and $30 \%$ water; and T5 - 60\% DCG and $40 \%$ water, aiming to obtain five treatments consisting of material containing approximately 90, 80, 70, 60 and $50 \%$ of dry matter (DM), respectively.

The silages were confectioned using PVC silos with $0.1 \mathrm{~m}$ diameter and $0.35 \mathrm{~m}$ height, with a volume of $2.75 \times 10^{-3} \mathrm{~m}^{3}$, provided with a Bunsen-type valve to prevent the ingress of air and allow for free escape of the fermentation gases. Aiming to homogenize the specific mass $\left.(\mathrm{kg} \mathrm{m})^{-3}\right)$ for all treatments, the silos were weighed at filling for treatment $\mathrm{T} 1$, in which the average specific mass of $700 \pm 3.22 \mathrm{~kg} \mathrm{NM} \mathrm{m}^{-3}$ was obtained and used as default for the other treatments. The silos were compressed using a wooden stick that allowed for the expulsion of air from the ensiled material. Silos were sealed with plastic tape and stored under shade at room temperature and opened in different periods: 14 , 28 and 42 days.

For quantitative evaluations of the effluent produced, non-woven fabric (TNT) bags containing sand previously dried in a forcedventilation oven $\left(55^{\circ} \mathrm{C}\right)$ for one day were placed at the bottom of the silos. To prevent errors in weighing after the silos were opened, the ensiled material was separated from the sand bags by using a polyethylene screen.

The effluent production ( $\%$ of natural matter of the ensiled sample $\left[\mathrm{NMS}_{\mathrm{ens}}\right]$ ) was calculated as the difference between the weights of the set (silo + silo lid + TNT bag with sand + polyethylene screen) before and after each ensilage, in relation to the $\mathrm{NMS}_{\text {ens }}$ (Jobim et al., 2007).

The loss of DM resulting from gas production (GL, \% of ensiled DM) was determined as the difference between the total weight of the set at ensiling and at opening TWS $_{\text {ens }}$ and $\mathrm{TWS}_{\text {open }}$; sample + silo + silo lid + TNT bag with sand + polyethylene screen) and the weight of the set at ensiling $\left(\mathrm{WS}_{\mathrm{ens}}\right.$; silo + silo lid + TNT bag with sand + polyethylene screen), respectively, in 
relation to the amount of DM ensiled and at opening, according to the equation: $\mathrm{GL}=$ $\left[\left(\mathrm{TWS}_{\mathrm{ens}}-\mathrm{WS}_{\mathrm{ens}}\right) \times \mathrm{DM}_{\mathrm{ens}}\right]-\left[\left(\mathrm{TWS}_{\mathrm{open}}-\mathrm{WS}_{\mathrm{ens}}\right)\right.$ $\left.\times \mathrm{DM}_{\text {open }}\right] /\left[\left(\mathrm{TWS}_{\mathrm{ens}}-\mathrm{WS}_{\mathrm{ens}}\right) \times \mathrm{MS}_{\text {ens }}\right] \times 100$ (Jobim et al., 2007).

The total dry matter loss (TDML) was determined as the difference between the total weight of the set at ensiling and at opening

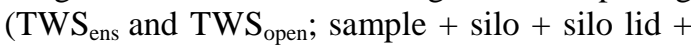
TNT bag with sand + polyethylene screen) and the weight of the set at ensiling and opening $\left(\mathrm{WS}_{\mathrm{ens}}\right.$ and $\mathrm{WS}_{\text {open }}$; silo + silo lid + TNT bag with sand + polyethylene screen), respectively, in relation to the amount of DM ensiled and at opening, according to the equation (Jobim et al., 2007): TDML $=\left[\left(\mathrm{TWS}_{\mathrm{ens}}-\mathrm{WS}_{\mathrm{ens}}\right) \times \mathrm{DM}_{\mathrm{ens}}\right]-$ $\left[\left(\mathrm{TWS}_{\text {open }}-\mathrm{WS}_{\text {open }}\right) \times \mathrm{DM}_{\text {open }}\right] /\left[\left(\mathrm{TWS}_{\mathrm{ens}}-\right.\right.$ $\left.\left.\mathrm{WS}_{\mathrm{ens}}\right) \times \mathrm{DM}_{\mathrm{ens}}\right] \times 100$.

Samples $(500 \mathrm{~g})$ of the ensiled material and the final material obtained after opening were collected to determine the chemical composition and for analysis of $\mathrm{pH}$ on a table-top $\mathrm{pH}$ meter (PHS-3B from PHTEK) and titratable acidity, according to the method described by Silva and Queiroz (2002).

The samples used to determine the chemical composition were pre-dried at $55^{\circ} \mathrm{C}$ for $72 \mathrm{~h}$ in a forced-ventilation oven immediately after silo opening. After pre-drying, the samples were ground in a knife mill with 1-mm mesh sieve and stored in labeled plastic jars for subsequent analyses. Dry matter (DM), organic matter $(\mathrm{OM})$, crude protein $(\mathrm{CP} ; \mathrm{N} \times 6.25)$, ether extract (EE) and neutral detergent fiber (NDF; using thermo-stable $\alpha$-amylase) contents were analyzed according to AOAC (Official..., 1990) method. The method described by Licitra et al. (1996) was used in the analysis of non-protein nitrogen (NPN).
The experiment was conducted in a completely randomized $(5 \times 3)$ factorial arrangement, with three replicates per treatment, which were composed of five levels of inclusion of water $(0$, $10,20,30$ and $40 \%$ of the FM) and three fermentation periods (14, 28 and 42 days), totaling 45 experimental silos.

All variables were subjected to analysis of variance according to the response surface model (PROC RSREG - SAS), considering the following statistical model:

$Y i j=\mu+A i+P j+A i^{2}+P k^{2}+A i * P j+e i j k$,

where: $\mathrm{Yij}=$ observed response at time $\mathrm{j}$ subjected to the water level i; $\mu=$ observed overall mean; $\mathrm{Ai}$ and $\mathrm{Ai}^{2}=$ effect of water level $\mathrm{i}, \mathrm{i}=(0,10,20,30$ and 40$) ; \mathrm{Pj}$ and $\mathrm{Pj}^{2}=$ effect of fermentation period $(14,28$ and 42$) ; \mathrm{Ai}^{*} \mathrm{Pj}=$ effects of the interaction between water level and fermentation period; and eij= random error associated with each observation.

For the variables in which the response surface model did not converge to a minimum or maximum point, linear or quadratic regression models (PROC REG - SAS) were adjusted according to the significance of the parameters observed in the statistical model. For all evaluated models, a significance level of 0.05 was considered for type-I error.

\section{RESULTS AND DISCUSSION}

The dry matter (DM) contents of the reconstituted corn grain varied with the increase in the water levels, probably due to a dilution effect (Table 1). However, there were no changes in the OM, CP, EE and NDF (\% DM) contents of reconstituted corn grain with inclusion of water before ensiling.

Table 1. Chemical composition of corn grain reconstituted with water before ensiling

\begin{tabular}{lccccc}
\hline Water inclusion levels (\%) & DM (\%) & OM (\%DM) & CP (\%DM) & EE (\%DM) & $\begin{array}{c}\text { NDF } \\
(\% \mathrm{DM})\end{array}$ \\
\hline 0 & 85.43 & 98.19 & 10.49 & 3.96 & 13.08 \\
10 & 76.49 & 97.95 & 10.24 & 3.93 & 13.04 \\
20 & 67.33 & 98.19 & 10.09 & 4.15 & 12.27 \\
30 & 61.58 & 98.30 & 10.44 & 4.09 & 11.88 \\
40 & 54.92 & 98.50 & 10.48 & 4.22 & 13.17 \\
\hline
\end{tabular}

DM, dry matter; OM, organic matter; CP, crude protein; EE, ether extract, NDF, neutral detergent fiber. 
Regarding the chemical composition of the silage of reconstituted corn grain, the DM contents showed a minimum level of $54.28 \%$ according to the response surface model with inclusion of $40 \%$ of water in the fermentation period of 42 days (Table 2). Reduction in the DM contents was expected, because as water is included there is an increase in the moisture contents of the ensiled mass. However, the OM contents increased linearly with water inclusion. Nevertheless, this variable showed a saddle point according to the response surface model, and so the parameters that were significant in this model were studied and the simple linear regression model was adjusted according to the water levels, displaying a $0.0187 \%$ increase for every $1 \%$ of water included.

Table 2. Estimates of the parameters of the response surface models for chemical composition of silage of corn grain reconstituted with different water levels and fermentation periods

\begin{tabular}{|c|c|c|c|c|c|c|c|c|}
\hline \multicolumn{2}{|c|}{ Parameters } & \multicolumn{2}{|c|}{$\mathrm{DM}(\%)$} & $\begin{array}{c}\mathrm{OM} \\
(\% \mathrm{DM}) \\
\end{array}$ & $\begin{array}{c}\mathrm{CP} \\
(\% \mathrm{DM}) \\
\end{array}$ & $\begin{array}{c}\mathrm{EE} \\
(\% \mathrm{DM}) \\
\end{array}$ & $\begin{array}{l}\text { NDF } \\
(\% \mathrm{DM})\end{array}$ & $\begin{array}{c}\text { NPN } \\
(\% \mathrm{TN})\end{array}$ \\
\hline \multicolumn{2}{|l|}{ Intercept } & \multicolumn{2}{|c|}{$86.57 *$} & $98.34 *$ & $8.94^{*}$ & 0.79 & $14.55^{*}$ & -0.73 \\
\hline \multicolumn{2}{|l|}{$\mathrm{W}$} & \multicolumn{2}{|c|}{$-1.04 *$} & $-0.02 *$ & -0.03 & $0.08 *$ & $-0.11 *$ & $1.12 *$ \\
\hline \multicolumn{2}{|l|}{$\mathrm{W}^{2}$} & \multicolumn{2}{|c|}{$0.0072 *$} & -0.0002 & $0.0009 *$ & -0.007 & $0.0022 *$ & $-0.01^{*}$ \\
\hline \multicolumn{2}{|l|}{$\mathrm{FP}^{2}$} & \multicolumn{2}{|c|}{0.00007} & 0.0003 & -0.0013 & -0.003 & 0.0012 & -0.02 \\
\hline \multicolumn{2}{|l|}{$\mathrm{W} \times \mathrm{FP}$} & \multicolumn{2}{|c|}{-0.0011} & 0.0003 & -0.0016 & -0.0011 & -0.0005 & 0.004 \\
\hline Maximum & $\begin{array}{l}\text { W } \\
\text { FP }\end{array}$ & & & & & $\begin{array}{l}37.19 \\
25.27\end{array}$ & & $\begin{array}{c}40 \\
22.28\end{array}$ \\
\hline Saddle & $\begin{array}{l}\text { W } \\
\text { FP }\end{array}$ & & & $\begin{array}{c}40 \\
7\end{array}$ & $\begin{array}{l}34.29 \\
20.57\end{array}$ & & & \\
\hline $\begin{array}{l}\text { Variable value } \\
P \text { model } \\
\mathrm{R}^{2}\end{array}$ & & $\begin{array}{r}5 \\
<0 \\
0\end{array}$ & & $\begin{array}{c}98.71 \\
<0.0001 \\
0.93\end{array}$ & $\begin{array}{c}9.52 \\
<0.0001 \\
0.78\end{array}$ & $\begin{array}{c}4.52 \\
0.018 \\
0.2975\end{array}$ & $\begin{array}{c}11.98 \\
0.0081 \\
0.33\end{array}$ & $\begin{array}{c}46.66 \\
<0.0001 \\
0.96\end{array}$ \\
\hline $\begin{array}{l}\mathrm{OM} \\
\mathrm{CP}\end{array}$ & $\begin{array}{l}97.86 \\
10.73\end{array}$ & $\begin{array}{l}98.11 \\
10.28\end{array}$ & $\begin{array}{c}98.36 \\
9.33\end{array}$ & $\begin{array}{c}98.47 \\
9.54\end{array}$ & $\begin{array}{c}98.62 \\
9.42\end{array}$ & $\begin{array}{c}\mathrm{Y}=97.91+0.0187 * \mathrm{~W} \\
\mathrm{Y}=10.77-0.07 * \mathrm{~W}+0.0009 * \mathrm{~W}^{2}\end{array}$ & $\begin{array}{l}<0.0001 \\
<0.0001\end{array}$ & $\begin{array}{l}0.82 \\
0.62\end{array}$ \\
\hline
\end{tabular}

$\mathrm{W}$, water (\%); FP, fermentation periods (days); DM, dry matter; OM, organic matter; CP, crude protein; EE, ether extract; NDF, neutral detergent fiber; NPN, non-protein nitrogen; TN, total nitrogen. ${ }^{*}$ Significant at $5 \%$ probability by the $\mathrm{F}$ test.

The crude protein (CP) contents also showed a saddle point and based on the significant parameters the quadratic model was adjusted as a function of the water levels; the minimum value of $9.41 \%$ of DM was obtained with addition of $38.88 \%$ of water. The decrease in the $\mathrm{CP}$ values can be possibly explained by the degradation of the protein compounds via the activity of microorganisms, which is also demonstrated by the increase in the NPN/TN contents as the water levels are increased. The values obtained in this experiment for $\mathrm{CP}$ are above the 8.71 and $8,9 \%$ of DM obtained for silage of corn grain with 35 and $30 \%$ of moisture at 64 and 30 days after ensiling, respectively (Morais et al., 2012; Ferraretto et al., 2018).

However, the EE contents showed a maximum point with inclusion of water throughout the fermentation period. The maximum value of $4.52 \%$ DM was obtained with addition of
$37.19 \%$ water and at 26 days of fermentation. The elevations in the EE contents with inclusion of water were unexpected, but, according to Bergamaschine et al. (2006), in the analysis of this compound of minerals with corn there may be losses of pigments such as carotene, which are extracted with ether and overestimate the fat values.

The NDF contents showed a minimum point according to the response surface model. The minimum value of $11.98 \% \mathrm{DM}$ was estimated with inclusion of $27.8 \%$ water and at 33 days of fermentation. The reductions in the NDF contents with inclusion of water might have stemmed from the enzymatic activity of the ensiled material, which resulted in hydrolysis of starch and hemicellulose, producing monosaccharides, which then provided additional available sugar for the lactic fermentation (McDonald et al., 1991), leading to 
lower final $\mathrm{pH}$ values and higher titratable acidity for the treatments with higher levels of water.

The NPN/TN contents in the silage of reconstituted corn grain showed a maximum point according to the response surface model, with an estimated value of $46.66 \% \mathrm{DM}$ with addition of $40 \%$ water and with a fermentation period of 23 days. The increase in the NPN/TN contents with inclusion of water can be explained by the proteolysis that occurred during fermentation, which led to degradation of the protein compounds, thereby resulting in greater contents of free amino acids and low-molecularweight peptides, which are the components of the NPN (Jobim et al., 2007).
The total losses of effluent (TEL) and dry matter (TDML) observed in the silage showed a saddle point according to the response surface model (Table 3). Therefore, the parameters that were significant in these models were studied and the quadratic model was adjusted as a function of the water inclusion levels with minimum values of 0 with water inclusion of 10.75 and $8.75 \%$ for TEL and TDML, respectively. According to McDonald et al. (1991), the threshold value considered adequate for TEL in silages varies from 5 to $7 \%$ of the total losses, which was exceeded $(11.65 \%)$ with inclusion of $40 \%$ of water.

Table 3. Estimate of the parameters of the response surface models for fermentative profile of the silage of corn grain reconstituted with different water levels and fermentation periods

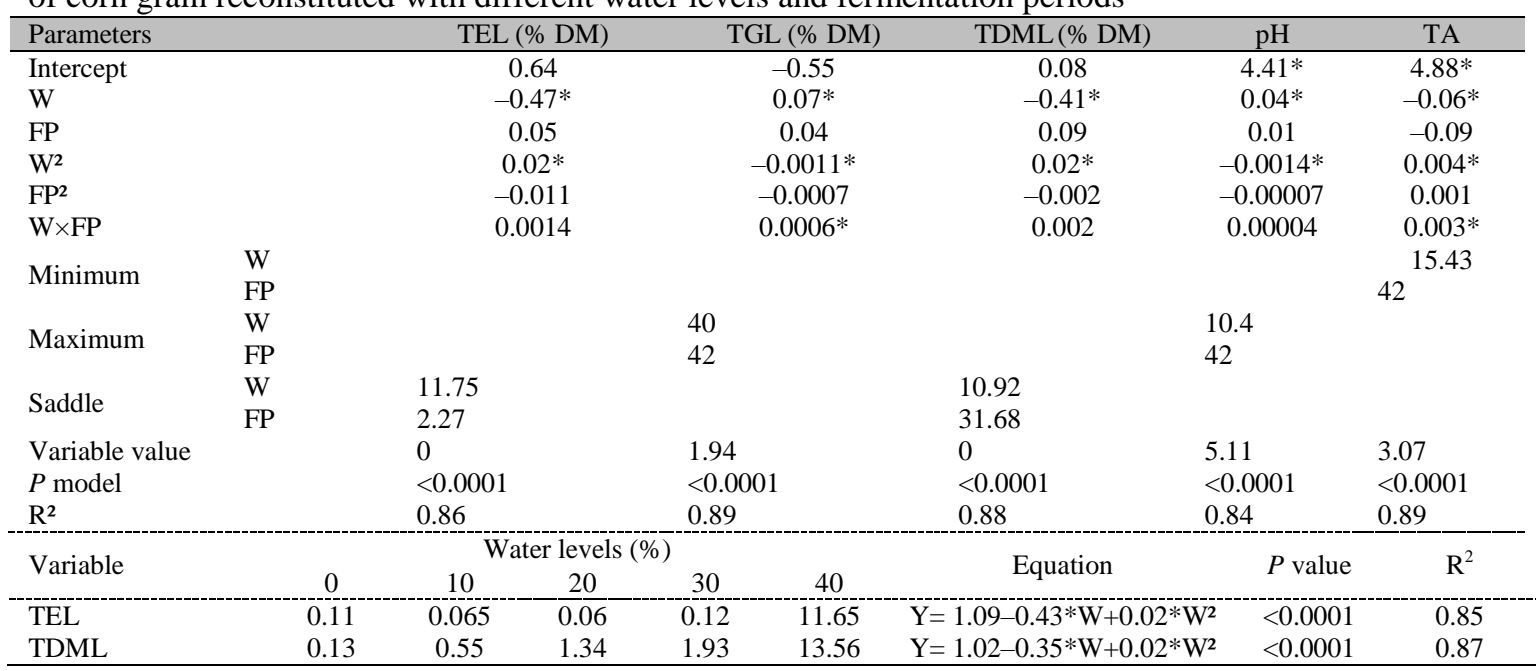

W, water (\%); FP, fermentation periods (days); TEL, total effluent losses; TGL, total gas losses; TDML, total dry matter losses; TA, titratable acidity $(\mathrm{mL}$ of $\mathrm{NaOH} 0.1 \mathrm{~N}$ until reaching $\mathrm{pH} 7.0)$. ${ }^{*}$ Significant at $5 \%$ probability by the F test.

Results obtained by Pereira (2012) also show high levels of effluent losses for the treatments with $38 \%$ of moisture in the silage of reconstituted finely-ground corn and silage of reconstituted coarsely-ground corn, in which 7.20 and $8.15 \%$, respectively, were obtained after 56 days of ensilage. In a study conducted by Mombach et al. (2018) for silage of reconstituted corn grain, the obtained DM loss value was 1.33 for $66.3 \%$ of moisture, value very close to that found in this experiment.

The total gas losses (TGL) showed a maximum point according to the response surface model, displaying the maximum value of $1.94 \%$ DM with inclusion of $40 \%$ water and with 42 days of fermentation. Yet, even though TGL increased with elevation in the water levels, the values remained within the range deemed acceptable for silages ( 1 to $2 \%$ of the total energy losses), since this type of loss is considered inevitable during the ensiling process (McDonald et al., 1991). 
The values obtained in this experiment are very close to those found by Andrade Filho et al. (2010), who evaluated three levels of reconstitution in the ensilage of dry corn grains, obtaining gas-loss values of 1.91, 1.80 and $1.70 \%$ for 20,30 and $40 \%$ of moisture, respectively. In rehydrated corn grain silage at 124 days of fermentation, Silva et al. (2018) also verified values close of this experiment $(1,65 \%$ DM).

The $\mathrm{pH}$ values of this experiment also showed a maximum point according to the response surface model (Figure 1). The maximum value of 5.11 was obtained with addition of $10.4 \%$ of water and at 42 days of fermentation. Andrade
Filho et al. (2010) and Mombach et al. (2018) and found very similar values in silages of dry corn grain reconstituted (5.35 and 4.8, respectively).

In experiments with reconstitution of dry sorghum grain at three moisture levels, Huck et al. (1999) found $\mathrm{pH}$ values of 5.0, 4.4 and 4.05 for the DM contents of 75, 60 and $55 \%$, respectively, which are very similar to those of the present study. However, Ferraretto et al. (2018) found a slightly lower $\mathrm{pH}$ for silages of corn grain reconstituted with $30 \%$ moisture. The obtained $\mathrm{pH}$ data was 4.0 for silage with 28 days fermentation.

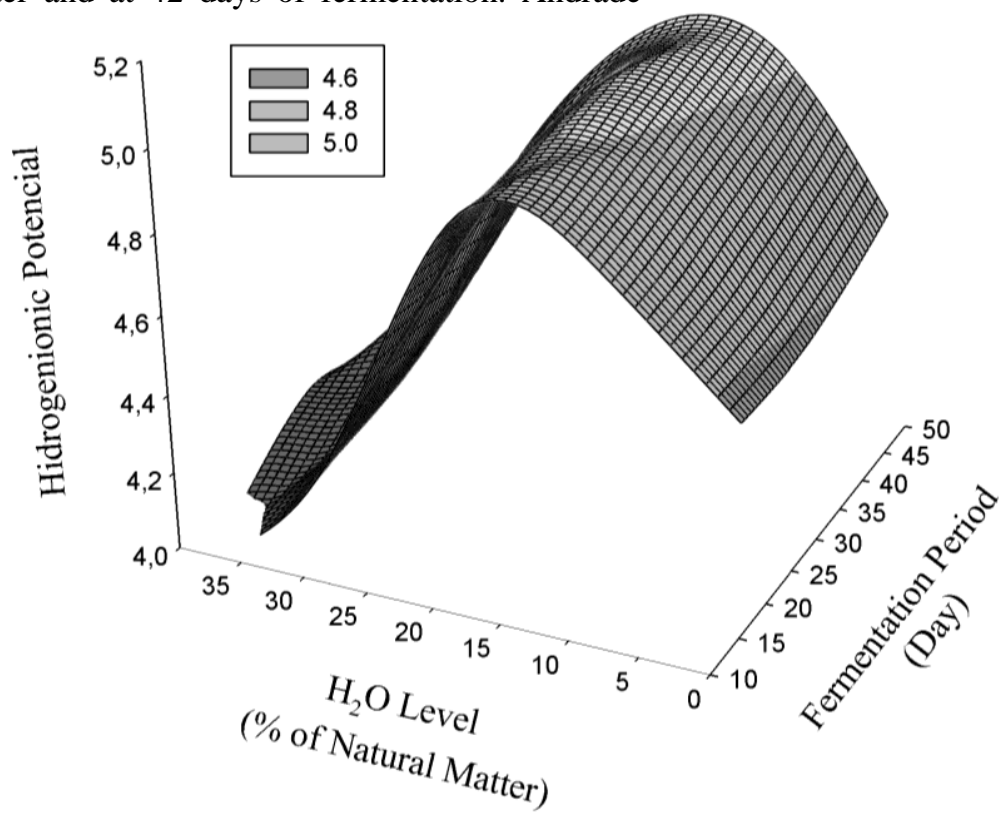

Figure 1. Response surface for the hydrogenionic potential $(\mathrm{pH})$ of silage of corn reconstituted with different water levels and fermentation periods.

Nonetheless, measuring the $\mathrm{pH}$ value isolated cannot be considered a safe criterion to evaluate fermentations, because its inhibitory effect on the bacteria depends on the level of declination of the ionic concentration and the moisture content of the medium (Woolford, 1984). According to Jobim et al. (2007), the most suitable indicator to determine the fermentation quality is the concentration of undissociated organic acids, represented by the titratable acidity.

The importance of determining the titratable acidity is based on the fact that the $\mathrm{pH}$ does not maintain a direct relationship with the lactic acid content of the silage, which should contribute to reduce it. This is because there are other ions and ingredients added during the ensiling process which interfere with the relationship of the $\mathrm{pH}$ with lactic acid (Silva and Queiroz, 2002).

Unlike what was observed with $\mathrm{pH}$, the treatments with inclusion of 0,10 and $20 \%$ water in the ensiled mass resulted in lower values for titratable acidity (TA) in comparison with the treatments with 30 and $40 \%$ water inclusion (Figure 2). According to the response surface model this variable showed a minimum point with 3.07 , estimated with addition of $15.43 \%$ water and with 42 days of fermentation. 


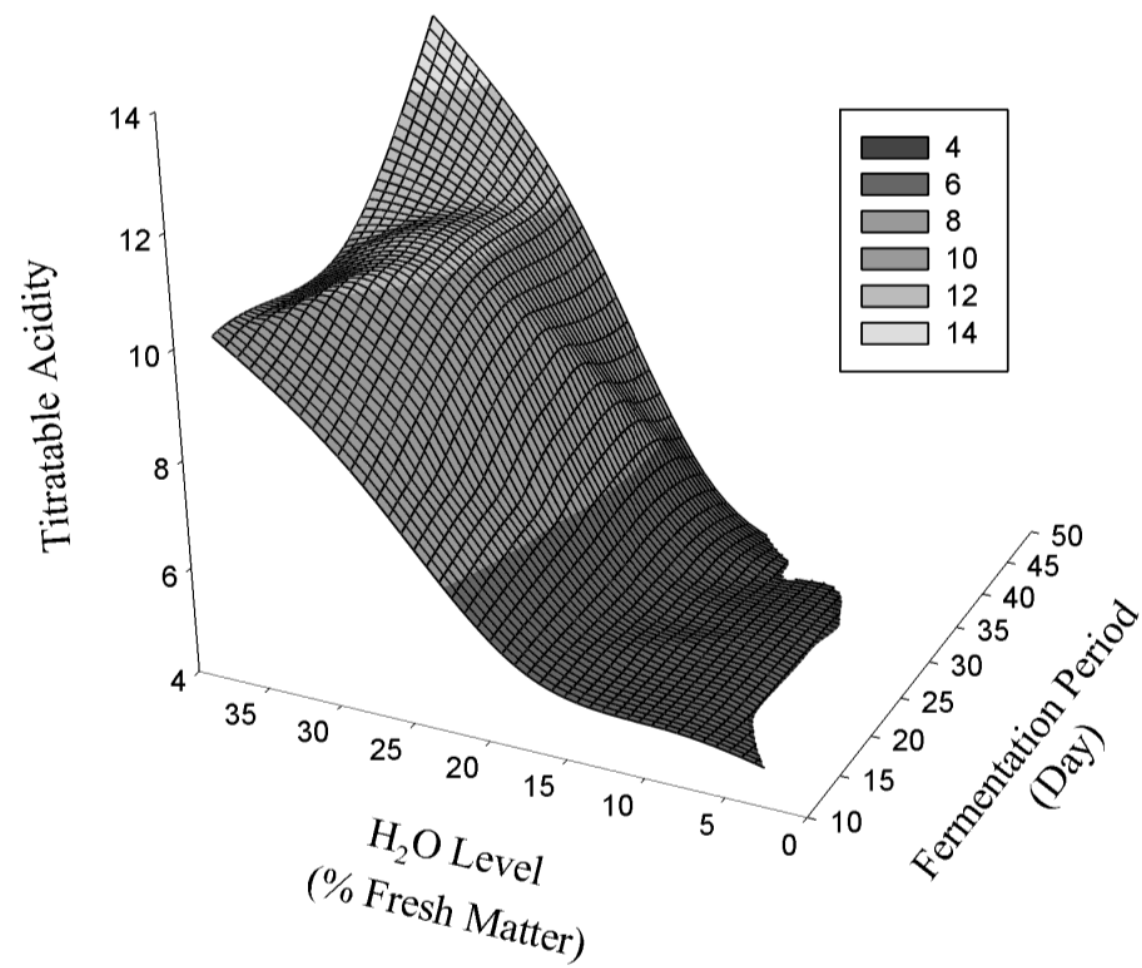

Figure 2. Response surface for the titratable acidity of the silage of corn grain reconstituted with different water levels and fermentation periods.

By correlating the $\mathrm{pH}$ and $\mathrm{TA}$ it is possible to infer that fermentation stability was more extensive with the water inclusion levels of 0,10 and $20 \%$ until 42 days of ensilage. This is explained not only by the high $\mathrm{pH}$, but also the low TA in these treatments, indicating that there was no significant production of lactic acid by the homofermentative lactic acid bacteria, which is a process that usually takes place in silages. For the water inclusion levels of 30 and $40 \%$, however, there was a marked reduction in $\mathrm{pH}$ in relation to the other treatments and a considerable increase in the TA values, which is possibly explained by the greater lactic acid production.

\section{CONCLUSION}

The rehydration with $30 \%$ of water inclusion in the natural matter of dry corn grain, allows its storage as silage, with low $\mathrm{pH}$ levels and high levels of titratable acidity, with a better fermentative profile. In addition, this water level resulted in low effluent and dry matter losses.

\section{REFERENCES}

ANDRADE FILHO, R.; REIS, R.B.; PEREIRA, M.N.; ANTENOR, M. Degradabilidade ruminal in situ de grãos de milho maduros do tipo flint ou dentado, secos ou reconstituídos e ensilado. In: REUNIÃO ANUAL DA SOCIEDADE BRASILEIRA DE ZOOTECNIA, 42., 2010, Salvador. Anais... Salvador: UFBA, 2010. (Resumo).

BERGAMASCHINE, A.F.; PASSIPIÉRI, M.; VERIANO FILHO. W.V. et al. Qualidade e valor nutritivo de silagens de capim-marandu ( $B$. brizantha $\mathrm{cv}$. Marandu) produzidas com aditivos ou forragem emurchecida. Rev. Bras. Zootec. v.35, p.1454-1462, 2006.

FERRARETTO, L.F.; SILVA FILHO, W.I.; FERNANDES, T. et al. Effect of ensiling time on fermentation profile and ruminal in vitro starch digestibility in rehydrated corn with or without varied concentrations of wet brewers grains. J. Dairy Sci., v.101, p.4643-4649, 2018. 
HUCK, G.L.; KREIKEMEIER, K.K.; BOLSEN, K.K. Effect of reconstituting field-dried and early-harvested sorghum grain on the ensiling characteristics of the grain and on growth. $J$. Anim. Sci., v.77, p.1074-1081, 1999.

JOBIM, C.C.; NUSSIO, L.G.; REIS, R.A. et al. Avanços metodológicos na avaliação da qualidade da forragem conservada. Rev. Bras. Zootec., v.36, p.101-119, 2007.

LEVANTAMENTO sistemático da produção agrícola. Rio de Janeiro: IBGE, 2018. Available in: <https://sidra.ibge.gov.br/home/lspa/matogrosso>. Accessed in: 10 Oct. 2018.

LICITRA, G.; HERNANDEZ, T.M.; VAN SOEST, P.J. Standardization of procedures for nitrogen fractionation of ruminant feeds. Anim. Feed Sci. Technol., v.57, p.347-358, 1996.

MCALLISTER, T.A.; PHILLIPE, R.C.; RODE, L.M.; CHENG, K.J. Effect of the protein matrix on the digestion of cereal grains by ruminal microorganisms. J. Anim. Sci., v.71, p.205-212, 1993.

MCDONALD, P.; HENDERSON, A.R.; HERON, S.J.E. (Eds.). The biochemistry of silage. 2.ed. Marlow: Chalcombe Publications., 1991. 340p.

MOMBACH, M.A.; PEREIRA, D.H.; PINA, D.S. et al. Rehydration of dry corn grain as an alternative for conservation purposes. Aust. J. Crop Sci., v.12, p.1472-1478, 2018.
MORAIS, M.G.; ÍTAVO, C.C.B.F.; ÍTAVO, L.C.V. et al. Inoculação de silagens de grãos úmidos de milho, em diferentes processamentos Rev. Bras. Saúde Prod. Anim., v.13, p.969-981, 2012.

OFFICIAL methods of analysis. 15.ed. Arlington: Association Official of Analytical Chemistry, 1990. 771p.

PEREIRA, M.L.R. Degradabilidade ruminal in vitro de grão reidratado e ensilado de milho $e$ sorgo com diferentes granulometrias. 2012. 73f. Dissertação (Mestre em Ciência Animal) Escola de Veterinária e Zootecnia, Universidade Federal de Goiás, Goiânia, GO.

REIS, W.; JOBIM, C.C.; MACEDO, F.A.F. et al. Características da carcaça de cordeiros alimentados com dietas contendo grãos de milho conservados em diferentes formas. Rev. Bras. Zootec., v.30, p.1308-1315, 2001.

SILVA, D.J.; QUEIROZ, A.C. (Eds.). Analise de alimentos: métodos químicos e biológicos. 3.ed. Viçosa, MG: UFV, 2002. 235p.

SILVA, N.C.; NASCIMENTO, C.F.; NASCIMENTO, F.A. et al. Fermentation and aerobic stability of rehydrated corn grain silage treated with different doses of Lactobacillus buchneri or a combination of Lactobacillus plantarum and Pediococcus acidilactici. J. Dairy Sci., v.101, p.4158-4167, 2018.

WOOLFORD, M.K. The silage fermentation. New York: Marcel Deckker, 1984. 350p. 